\title{
Note \\ Characterization of endospore-forming bacteria associated with entomopathogenic nematodes, Heterorhabditis spp., and description of Paenibacillus nematophilus sp. nov.
}

\author{
Correspondence \\ Michael R. Enright \\ michael.r.enright@may.ie
}

\author{
Michael R. Enright,, ${ }^{1,2}$ James O. Mclnerney ${ }^{2}$ and Christine T. Griffin ${ }^{1,2}$ \\ Institute of Bioengineering and Agroecology ${ }^{1}$ and Department of Biology ${ }^{2}$, National University \\ of Ireland, Maynooth, Co. Kildare, Ireland
}

\begin{abstract}
Endospore-forming bacteria were isolated from insect-pathogenic nematodes, Heterorhabditis spp., from three diverse geographical locations. Spindle-shaped sporangia of these bacteria adhere to the free-living infective stage of the nematode, which carries them to new insect hosts, where the bacterium reproduces. These isolates were characterized based on phenotypic and chemotaxonomic properties and 16S rRNA gene sequences. Analysis of the 16S rRNA gene placed the isolates within the genus Paenibacillus. The isolates shared higher sequence similarities with each other $(95 \cdot 1-100 \%)$ than they did with any other named species within the genus (89-2-94\%). Paenibacillus macquariensis, Paenibacillus azoreducens, Paenibacillus amylolyticus and Paenibacillus durus were among the species with highest sequence similarity to these isolates. The isolates shared a high degree of phenotypic similarity and were easily distinguished from closely related members of the genus. Anteiso- $C_{15: 0}$ and $C_{16: 0}$ were among the major fatty acid types and the DNA G $+C$ content was approximately 44 mol\% in all isolates. DNA-DNA similarity studies revealed genomic heterogeneity among the isolates, such that they are likely to represent more than one species. Two of the isolates (both from a Heterorhabditis megidis isolate from Estonia) are phenotypically distinguishable from the others and are proposed as a single species, Paenibacillus nematophilus sp. nov. The type strain for this novel species is NEM1 $\mathrm{a}^{\top}$ $\left(=\mathrm{DSM} 13559^{\top}=\mathrm{NCIMB} 13845^{\top}\right)$. The other isolates, although closely related to the proposed species, are likely to represent at least one, but most likely two, novel species.
\end{abstract}

The genus Paenibacillus includes several species that are associated with dead insects in one way or another. Amongst these are obligate insect pathogens such as Paenibacillus popilliae, Paenibacillus lentimorbus and Paenibacillus larvae (Pettersson et al., 1999), as well as non-pathogens/facultative pathogens such as Paenibacillus apiarus (Nakamura, 1996) and Paenibacillus alvei (Krieg, 1981). Enright et al. (2001) found a Paenibacillus sp. associated with an insectpathogenic nematode, Heterorhabditis megidis EU17. This nematode was isolated during a survey conducted in Estonia (Griffin et al., 1999).

Heterorhabditis spp. nematodes are lethal pathogens of insects. Infective juveniles (IJs), the only infective stage of

Abbreviation: IJ, infective juvenile.

The GenBank/EMBL/DDBJ accession numbers for the $16 \mathrm{~S}$ rRNA gene sequence of strains NEM1 $a^{\top}, N E M 1 b, N E M 2$ and NEM3 are respectively AF480935, AF480937, AF480936 and AF480934.

A list of the accession numbers of reference sequences used in the phylogenetic analysis is available as supplementary material in IJSEM Online (http://ijs.sgmjournals.org). these nematodes, carry in their intestine a symbiotic bacterium belonging to the genus Photorhabdus (Forst et al., 1997). Upon infection of a suitable host insect, the symbiont is released into the haemocoel and causes the death of the insect within $48 \mathrm{~h}$ (Poinar, 1990). The Photorhabdus sp. then completely colonizes the dead insect cadaver, assisting in the breakdown of the insect tissues by secretion of an array of enzymes (Forst \& Nealson, 1996). It is upon this bacterium and the degraded tissues that the nematodes feed. The nematodes complete their development and reproduce within the dead host. Photorhabdus spp. also produce several antibiotics (Forst \& Nealson, 1996). Together, these have a broad spectrum of activity (Akhurst, 1982) and help to ensure the dominance of Photorhabdus within the insect cadaver (Forst et al., 1997). Until its nutritive status declines, the insect cadaver supports several nematode generations. Thousands of the non-feeding IJs then emerge from the insect into the soil, in search of a new insect host (Poinar, 1990).

The association reported by Enright et al. (2001) involves spindle-shaped swollen sporangia of a Paenibacillus sp. 
adhering to the surface of $H$. megidis EU17 nematode IJs (Fig. 1). There is a level of specificity to this adherence; sporangia adhere to IJs of all Heterorhabditis spp. tested and of closely related parasites of the order Strongylida but not to any other soil nematodes tested (Enright et al., 2001; M. R. Enright and C. T. Griffin, unpublished). Sporangia of closely related Paenibacillus species (eight species tested) did not adhere to Heterorhabditis spp. IJs (Enright et al., 2001). The Paenibacillus sp. reproduces within the dead insect despite the Photorhabdus-produced antibiotics and emerging IJs can then carry large numbers of its sporangia out of the cadaver. IJs bearing sporangia then infect new insect hosts. Other Heterorhabditis spp. strains have also been found in similar association with endosporeforming bacteria. We noted the presence of bacteria in a Heterorhabditis indica strain from India contained in our collection and a Heterorhabditis sp. from Georgia, USA, was found associated with a bacterium initially identified as a Bacillus species (Marti \& Timper, 1999). In both cases, the bacteria produced sporangia that were morphologically similar to those described by Enright et al. (2001). These bacteria-Heterorhabditis associations are recognizable by the tendency of the sporangia to 'clump' the nematodes in water (nematodes stick together in large cross-linked groups). In each of the cases mentioned, the nematodes were associated with the endospore-forming bacteria from the time that they where first isolated from soil (D. Marti and S. Easwaramoorthy, personal communication). In this paper, we have characterized four bacterial isolates that produce spindle-shaped sporangia and which were isolated from the H. megidis, H. indica and Heterorhabditis sp. strains

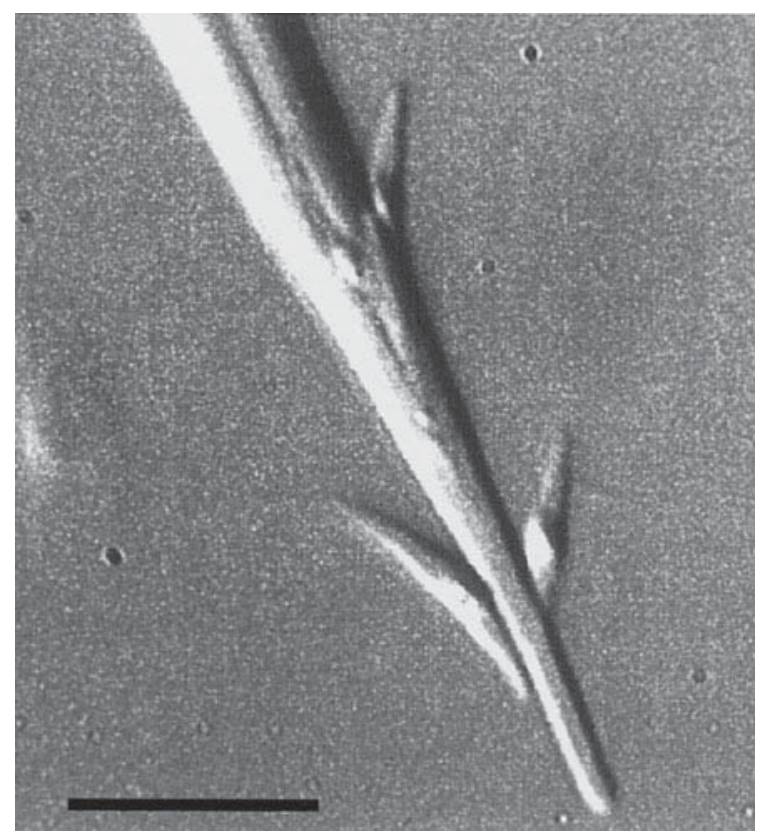

Fig. 1. Spindle-shaped Paenibacillus sp. sporangia adhering to the tail end of an $H$. megidis IJ. Bar, approx. $10 \mu \mathrm{m}$. mentioned above. A novel species, Paenibacillus nematophilus sp. nov., represented by two of these isolates, is proposed.

Bacteria were selectively isolated from Heterorhabditis nematodes based on resistance of their endospores to $0 \cdot 4 \%$ hyamine $\left(\mathrm{NEM}_{1} \mathrm{a}^{\mathrm{T}}\right)$ or heat (all other isolates). Standard heat-isolation procedures were followed. Isolates were chosen based on production of spindle-shaped sporangia capable of clumping Heterorhabditis spp. IJs. All isolations were done on nutrient agar, following incubation at $30^{\circ} \mathrm{C}$. Standard phenotypic characterization of these isolates was carried out using the methods described by Gordon et al. (1973), Parry et al. (1983), Smibert \& Krieg (1994) and Claus \& Berkeley (1986), using appropriate Paenibacillus spp. controls. API tests (bioMérieux) were carried out as in Logan \& Berkeley (1984), except that, with API 50CHB tests, results were also recorded after 4 days. All tests were replicated at least twice. Growth under anaerobic conditions was tested using an anaerobic jar with an AnaeroGen sachet (Oxoid) according to the manufacturer's instructions. Fatty acid analysis was carried out at the DSMZ (Braunschweig, Germany) using high-resolution GC and the profile was analysed using the Microbial Identification System (MIDI; Microbial ID) according to the manufacturer's instructions. Both the $\mathrm{G}+\mathrm{C}$ content and DNA-DNA hybridization studies were also conducted at DSMZ. For these, DNA was isolated and purified according to the method of Cashion et al. (1977). In the G+C content studies, DNA was hydrolysed according to the method of Mesbah et al. (1989) and HPLC was performed as described by Tamaoka \& Komagata (1984). Calibrations were done as described by Mesbah et al. (1989). DNA-DNA hybridization studies were carried out as described by De Ley et al. (1970), with the modifications described by Huß et al. (1983) and Escara \& Hutton (1980). Renaturation rates were computed with the program TRANSFER.BAS (Jahnke, 1992).

Standard methods were used to extract bacterial genomic DNA before PCR amplification of almost the full-length 16S rRNA gene. Conserved eubacterial primers EB-27F (5' AGAGTTTGATCMTGGCTCAG- $3^{\prime}, \mathrm{M}=\mathrm{A}$ or C) and UN1492R (5'-TACGGYTACCTTGTTACGACTT-3', Y=C or $\mathrm{T})$ were used. PCR products were sequenced independently in both directions by Oswel Sequencing (Southampton, UK) using standard methods with an automated DNA sequencer and consensus sequences were determined. The 16S rRNA gene sequences of named Paenibacillus species and members of closely related genera were obtained from the GenBank database. All sequences were aligned using the program CLUSTAL X (Thompson et al., 1997). Accession numbers of reference sequences obtained from GenBank are available as supplementary material in IJSEM Online (http://ijs. sgmjournals.org). Short sequence stretches at both ends of the alignment were excluded because of large numbers of ambiguous positions before pairwise percentage similarities of the sequences were determined using the program PAUP ${ }^{*}$ (Sinauer). The alignment was then manipulated manually, whereby positions of uncertain homology were excluded, 
using the program SEAVIEW (Galtier et al., 1996). Further phylogenetic analyses using distance, parsimony and maximum-likelihood criteria were carried out using the program PAUP* . Confidence in phylogenetic hypotheses was assessed using the bootstrap $(n=1000)$ resampling method (Felsenstein, 1988) for distance and parsimony and quartet puzzling $(n=1000)$ (Strimmer \& Von Haeseler, 1996) for maximum-likelihood.

Selective isolations from the various sporangia-associated nematode strains yielded numerous slow-growing bacterial isolates, all with similar colony morphology and all of which met the selection criteria employed. Four isolates, with at least one from each nematode strain, were chosen for further study. Isolates NEM $1 \mathrm{a}^{\mathrm{T}}$ and NEM1b were isolated from $H$. megidis EU17 (from Estonia), while NEM2 and NEM3 were respectively isolated from Heterorhabditis sp. 'Line1' (from Georgia, USA) and $H$. indica LN2 (from India). Vegetative cells of these isolates stained Gram-negative (Gram-variable in older cultures) and were motile and rod-shaped. All four isolates produced morphologically similar spindle-shaped sporangia, in which an ellipsoidal endospore occupied a central/paracentral position, clearly swelling the sporangium (Fig. 2). Endospores were retained within the sporangia. Colonies of all isolates were thin, non-pigmented, regular and smooth with an undulate edge. All four of these nematode-associated isolates were phenotypically very similar (Table 1).

Phylogenetic analysis based on 16S rRNA gene sequences, using distance, parsimony and maximum-likelihood criteria, showed that the four nematode-associated isolates

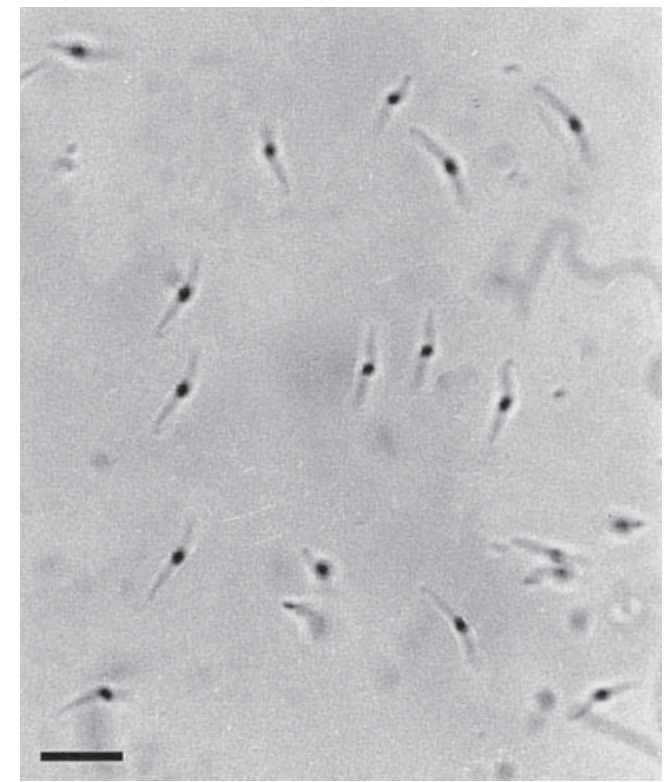

Fig. 2. Mature sporangia of Paenibacillus sp. $\mathrm{NEM}_{1} \mathrm{a}^{\top}$ from a 5-week-old culture, showing that the endospores have been retained within the sporangia. Bar, approx. $10 \mu \mathrm{m}$. formed a phylogenetically distinct group within the genus Paenibacillus, separate from all other named species. This relationship was strongly supported by bootstrap and quartet-puzzling analyses. All four isolates had higher sequence similarity to each other $(95 \cdot 1-100 \%)$ than they had to any other named member of the genus $(89 \cdot 2-94 \%)$. Isolate $\mathrm{NEM} \mathrm{a}^{\mathrm{T}}$ shared $100 \%$ sequence similarity (across 1442 alignment positions) with the other isolate from the same nematode strain, NEM1b. However, similarities between these and the other isolates were lower. $\mathrm{NEM}^{\mathrm{T}} \mathrm{a}^{\mathrm{T}}$ had $96 \cdot 3 \%$ sequence similarity to NEM2 and $95 \cdot 1 \%$ to NEM3, while NEM2 had $97 \cdot 1 \%$ similarity to NEM3. These results are indicative of possible heterogeneity at the species level within the group (Stackebrandt \& Goebel, 1994). Using the same alignment, Paenibacillus macquariensis was the named species with highest sequence identity to isolate $\mathrm{NEM}_{1 \mathrm{a}}{ }^{\mathrm{T}}$ (94\%), followed by Paenibacillus amylolyticus and Paenibacillus azoreducens (93.6\%), Paenibacillus borealis and Paenibacillus durus (93.5\%) and Paenibacillus macerans $(93 \cdot 4 \%)$. Most similar to isolate NEM2 was $P$. durus (93.3\%), while P. amylolyticus was most similar to isolate NEM3 (93·2\%). Across a shorter alignment (966 alignment positions), Paenibacillus illinoisensis and Paenibacillus chibensis were also among the species with higher sequence similarity to the nematode-associated isolates. The genomic heterogeneity of the nematode-associated isolates suggested by the $16 \mathrm{~S}$ rRNA sequences was confirmed by the results of DNA-DNA hybridization studies. Isolate NEM1a ${ }^{\mathrm{T}}$ shared $90 \cdot 3 \%$ DNA-DNA similarity with NEM1b, but only $40 \cdot 9$ and $38 \cdot 3 \%$ with isolates NEM2 and NEM3. Isolate NEM2 shared $60.4 \%$ DNA-DNA similarity with NEM3. In comparison, $\mathrm{NEM}_{1} \mathrm{a}^{\mathrm{T}}$ shared $25 \cdot 8 \%$ DNA-DNA similarity with $P$. azoreducens, one of the species with highest $16 \mathrm{~S}$ rRNA sequence identity to that isolate. According to the recommendations of Wayne et al. (1987), isolates should have similarity values of $70 \%$ or greater to be considered conspecific.

As is typical of Paenibacillus species (Ash et al., 1993), the fatty acids of the nematode-associated isolates were mainly of the straight-chain saturated, anteiso- and iso-branched types, with anteiso- $\mathrm{C}_{15}$ predominant, except in NEM2, where $\mathrm{C}_{16 \text { : } 0}$ was slightly higher. Analysis yielded two major fatty acid types, namely, anteiso- $\mathrm{C}_{15}$ and $\mathrm{C}_{16: 0}$ (Table 2). Straight-chain $\mathrm{C}_{14: 0}$ fatty acid was more common in the nematode-associated isolates than has been reported for most other Paenibacillus species (Shida et al., 1997a, b; Nakamura et al., 1996; Pettersson et al., 1999; Elo et al., 2001), an exception being $P$. borealis (Elo et al., 2001). While all the isolates shared a similar overall pattern, there were some differences between them in the actual levels of some fatty acids. For example, whereas NEM1 ${ }^{\mathrm{T}}$ and NEM1b had similar levels of anteiso- $\mathrm{C}_{17}$ (approx. 8\%), NEM2 and NEM3 had higher levels (13 and 16\%). Diagnostic amounts of $\mathrm{C}_{12: 0}$ and 3-hydroxy fatty acids were found in all of the nematode-associated isolates. These have normally been undetected or unreported for Paenibacillus species (Shida 
Table 1. Differential characteristics of the four nematode-associated isolates and selected Paenibacillus species

Strains/species: 1, NEM1a ${ }^{\mathrm{T}}$; 2, NEM1b; 3, NEM2; 4, NEM3; 5, P. macquariensis (data from Shida et al., 1997a; Heyndrickx et al., 1996b; Logan \& Berkeley, 1984); 6, P. amylolyticus (Shida et al., 1997b; Elo et al., 2001); 7, P. azoreducens (Meehan et al., 2001; this study); 8, P. borealis (Elo et al., 2001; this study); 9, P. macerans (Shida et al., 1997a; Logan \& Berkeley, 1984; Elo et al., 2001); 10, P. illinoisensis (Shida et al., 1997b; Elo et al., 2001); 11, P. chibensis (Shida et al., 1997b; Elo et al., 2001); 12, P. durus (Shida et al., 1997a; Elo et al., 2001); 13, P. polymyxa (Shida et al., 1997a; Logan \& Berkeley, 1984; Gordon et al., 1973; this study). +, Positive; -, negative; V, variable; W+, weakly positive (acid produced more slowly than from other carbohydrates). NR, Not reported.

\begin{tabular}{|c|c|c|c|c|c|c|c|c|c|c|c|c|c|}
\hline Characteristic & 1 & 2 & 3 & 4 & 5 & 6 & 7 & 8 & 9 & 10 & 11 & 12 & 13 \\
\hline Endospore position* & $\mathrm{C}$ & C & $\mathrm{C}$ & $\mathrm{C}$ & $\mathrm{T} / \mathrm{ST}$ & NR & $\mathrm{T} / \mathrm{ST}$ & $\mathrm{T} / \mathrm{ST}$ & $\mathrm{T} / \mathrm{ST}$ & $\mathrm{NR}$ & NR & NR & $\mathrm{C} / \mathrm{ST}$ \\
\hline ONPG hydrolysis & - & - & - & - & + & + & NR & + & + & NR & NR & NR & + \\
\hline Nitrate reduction & - & - & - & - & - & + & - & - & + & - & + & - & + \\
\hline \multicolumn{14}{|l|}{ Production of: } \\
\hline Acetylmethylcarbinol & + & + & + & + & - & - & - & - & - & - & - & + & + \\
\hline \multicolumn{14}{|l|}{ Hydrolysis of: } \\
\hline Casein & - & - & - & - & - & + & - & + & - & + & - & - & + \\
\hline Starch & + & + & + & + & + & + & + & - & + & + & + & - & + \\
\hline Aesculin & + & + & + & + & + & - & + & + & + & - & - & + & + \\
\hline Gelatin & - & - & - & - & - & + & + & - & $\mathrm{V}$ & + & - & - & + \\
\hline Litmus milk reaction & - & - & - & - & $\mathrm{NR}$ & - & + & + & + & + & - & NR & + \\
\hline Gas from carbohydrates & - & - & - & - & - & - & NR & + & + & - & - & NR & + \\
\hline \multicolumn{14}{|l|}{ Acid from: } \\
\hline Lactose & - & - & - & - & + & - & + & + & + & - & - & - & + \\
\hline L-Arabinose & - & - & - & - & - & + & - & + & + & + & + & + & + \\
\hline D-Fructose & - & - & - & - & + & + & + & + & + & + & + & + & + \\
\hline D-Galactose & - & - & - & - & + & + & + & + & + & + & + & + & + \\
\hline D-Xylose & - & - & - & - & + & + & + & + & + & + & + & - & + \\
\hline Glycerol & - & - & - & - & - & + & + & + & + & + & - & - & + \\
\hline D-Mannitol & - & - & - & - & + & + & + & + & + & + & + & - & + \\
\hline D-Ribose & - & - & + & + & + & + & + & - & + & + & + & - & + \\
\hline D-Mannose & + & - & + & - & V & + & + & + & + & + & - & + & + \\
\hline Melibiose & - & - & - & - & + & + & + & + & + & + & + & + & + \\
\hline Inositol & - & - & - & - & - & + & - & - & $\mathrm{V}$ & + & + & - & - \\
\hline Melezitose & - & - & - & - & - & + & + & + & + & + & + & + & V \\
\hline D-Raffinose & - & - & - & - & + & - & + & + & + & + & - & + & + \\
\hline Inulin & - & - & - & - & - & + & + & + & + & + & + & + & $\mathrm{V}$ \\
\hline 5-Keto-D-gluconate & $\mathrm{w}+$ & $\mathrm{w}+$ & $\mathrm{w}+$ & $\mathrm{w}+$ & - & - & - & - & V & - & - & - & V \\
\hline DNA G $+C$ content $(\mathrm{mol} \%)$ & $44 \cdot 0$ & $44 \cdot 2$ & $44 \cdot 4$ & $43 \cdot 9$ & 39 & 46 & 47 & 54 & $53-54$ & 48 & 53 & 50 & $43-46$ \\
\hline
\end{tabular}

${ }^{*}$ C, Central/paracentral; T, terminal; ST, subterminal.

et al., 1997a, b; Nakamura et al., 1996; Elo et al., 2001; Heyndrickx et al., 1996a; Meehan et al., 2001).

All of the nematode-associated isolates shared a high degree of phenotypic similarity and conformed to the description of the genus (Shida et al., 1997a). They could easily be distinguished from closely related species on the basis of numerous differential characteristics (Table 1). For example, the endospore was always located in a central/paracentral position, while a terminal/subterminal position is the most common in their closest relatives. Strains of some related Paenibacillus can have both. For example, while all Paenibacillus polymyxa strains produce terminal/subterminal endospores, some also produce sporangia with central/paracentral endospores (Logan \& Berkeley, 1984). Endospores of the nematode-associated isolates are retained within the sporangium, even following long periods of storage. This is not the case with the majority of other described Paenibacillus species (N. Logan, personal communication). All the nematode-associated isolates had distinct profiles in API tests, easily distinguishable from those of closely related species. In API $50 \mathrm{CHB}$ tests, $\mathrm{NEM}^{\mathrm{T}} \mathrm{a}^{\mathrm{T}}$ utilized 16 carbohydrate substrates out of 49, while NEM1b utilized 15, NEM2 utilized 17 and NEM3 utilized 16, with 15 of these being common to all four isolates. These numbers are low compared with those found for other Paenibacillus species in both this and previous studies (Logan \& Berkeley, 1984; Elo et al., 2001). Incubation of the API 50CHB tests for 
Table 2. Fatty acid composition of Heterorhabditis-associated Paenibacillus isolates and other Paenibacillus species

Values are percentages of total fatty acids. Strains: 1, NEM1a ${ }^{\mathrm{T}}$; 2, NEM1b; 3, NEM2; 4, NEM3; 5, P. borealis DSM $13188^{\mathrm{T}}$ (data from Elo et al., 2001); 6, P. azoreducens DSM 13822 ${ }^{\mathrm{T}}$ (Meehan et al., 2001); 7, P. chibensis NRRL B-142 ${ }^{\mathrm{T}}$ (Shida et al., 1997b); 8, P. amylolyticus NRRL NRS-290 ${ }^{\mathrm{T}}$ (Shida et al., 1997b); 9, P. macquariensis CIP $103269^{\mathrm{T}}$ (Shida et al., 1997a); 10, P. macerans JCM 2500 ${ }^{\mathrm{T}}$ (Shida et al., 1997b). NR, Not reported; ND, not detected.

\begin{tabular}{|c|c|c|c|c|c|c|c|c|c|c|}
\hline Fatty acid & 1 & 2 & 3 & 4 & 5 & 6 & 7 & 8 & 9 & 10 \\
\hline \multicolumn{11}{|l|}{ Saturated } \\
\hline $\mathrm{C}_{12: 0}$ & $1 \cdot 80$ & $2 \cdot 37$ & $2 \cdot 30$ & $2 \cdot 13$ & NR & NR & NR & NR & ND & ND \\
\hline $\mathrm{C}_{14: 0}$ & $15 \cdot 50$ & $14 \cdot 53$ & $16 \cdot 87$ & $8 \cdot 74$ & $18 \cdot 6$ & $3 \cdot 5$ & $0 \cdot 3$ & $0 \cdot 6$ & $0 \cdot 7$ & $3 \cdot 7$ \\
\hline $\mathrm{C}_{15: 0}$ & 0.91 & $1 \cdot 08$ & $0 \cdot 54$ & $0 \cdot 39$ & $<0 \cdot 2$ & $0 \cdot 1$ & 0.6 & $0 \cdot 5$ & $1 \cdot 2$ & $0 \cdot 5$ \\
\hline $\mathrm{C}_{16: 0}$ & $22 \cdot 71$ & $20 \cdot 17$ & $22 \cdot 35$ & $17 \cdot 41$ & $10 \cdot 0$ & $22 \cdot 1$ & $5 \cdot 3$ & $20 \cdot 1$ & $2 \cdot 9$ & $17 \cdot 9$ \\
\hline Iso $\mathrm{C}_{14: 0}$ & $1 \cdot 79$ & $1 \cdot 90$ & $2 \cdot 06$ & $1 \cdot 08$ & $4 \cdot 9$ & $0 \cdot 8$ & $0 \cdot 8$ & $0 \cdot 2$ & $0 \cdot 8$ & $1 \cdot 8$ \\
\hline Iso $\mathrm{C}_{15: 0}$ & $1 \cdot 35$ & $1 \cdot 52$ & $2 \cdot 08$ & $3 \cdot 06$ & $11 \cdot 5$ & $5 \cdot 9$ & $4 \cdot 0$ & $2 \cdot 9$ & $5 \cdot 2$ & $2 \cdot 6$ \\
\hline Iso $\mathrm{C}_{16: 0}$ & $13 \cdot 22$ & $12 \cdot 62$ & $14 \cdot 77$ & $11 \cdot 2$ & $10 \cdot 5$ & $8 \cdot 6$ & $12 \cdot 2$ & $4 \cdot 1$ & $2 \cdot 6$ & $17 \cdot 1$ \\
\hline Iso $C_{17: 0}$ & $1 \cdot 38$ & $1 \cdot 25$ & $2 \cdot 12$ & $3 \cdot 33$ & $4 \cdot 9$ & $5 \cdot 6$ & $3 \cdot 2$ & $5 \cdot 8$ & $0 \cdot 4$ & $4 \cdot 1$ \\
\hline Anteiso $\mathrm{C}_{15: 0}$ & $27 \cdot 66$ & $31 \cdot 17$ & $19 \cdot 09$ & $30 \cdot 71$ & $35 \cdot 2$ & $33 \cdot 9$ & $57 \cdot 8$ & $36 \cdot 9$ & $81 \cdot 0$ & $34 \cdot 5$ \\
\hline Anteiso $\mathrm{C}_{17: 0}$ & $8 \cdot 25$ & $7 \cdot 51$ & $12 \cdot 99$ & $16 \cdot 29$ & $2 \cdot 1$ & $19 \cdot 8$ & $14 \cdot 3$ & $11 \cdot 5$ & $0 \cdot 7$ & $16 \cdot 1$ \\
\hline \multicolumn{11}{|l|}{ Others } \\
\hline $\mathrm{C}_{16: 1} \omega 11$ & $\mathrm{ND}$ & ND & ND & $\mathrm{ND}$ & $1 \cdot 3$ & ND & ND & $0 \cdot 5$ & $0 \cdot 6$ & $0 \cdot 1$ \\
\hline Iso $\mathrm{C}_{16: 0} 3-\mathrm{OH}$ & $1 \cdot 22$ & $1 \cdot 37$ & $0 \cdot 34$ & $0 \cdot 64$ & NR & NR & NR & NR & NR & NR \\
\hline $\mathrm{C}_{17: 0} 2-\mathrm{OH}$ & $1 \cdot 5$ & $1 \cdot 61$ & $0 \cdot 99$ & $2 \cdot 14$ & NR & NR & NR & NR & NR & NR \\
\hline
\end{tabular}

2 days longer than described in Logan \& Berkeley (1984) resulted in positive results for utilization of 5-keto-Dgluconate by the nematode-associated isolates. This was not the case with control Paenibacillus species.

Differentiation of the nematode-associated isolates from $P$. macquariensis, the species with highest $16 \mathrm{~S}$ rRNA gene sequence identity to $\mathrm{NEM}^{\mathrm{T}} \mathrm{a}^{\mathrm{T}}$, is based on the position of the endospore within the sporangium, their inability to grow at $5^{\circ} \mathrm{C}$ and their Voges-Proskauer reaction, as well as their inability to utilize a wide range of carbohydrates (Table 1).

The nematode-associated isolates differed somewhat in the conditions under which growth occurred. All four isolates grew at between 15 and $37^{\circ} \mathrm{C}$. However, only NEM1a ${ }^{\mathrm{T}}$ and NEM1b grew at $10^{\circ} \mathrm{C}$. This finding may be linked to climatic differences between the geographical origins of the different isolates. None of the isolates grew at 5 or $40{ }^{\circ} \mathrm{C}$. Isolates NEM1a ${ }^{\mathrm{T}}$, NEM1b and NEM3 grew at $\mathrm{pH}$ 6-11, whereas NEM2 grew at $\mathrm{pH}$ 6-10. Isolates NEM1a ${ }^{\mathrm{T}}$ and NEM1b grew in $2 \%(\mathrm{w} / \mathrm{v}) \mathrm{NaCl}$, but not in $3 \%$, whereas NEM2 and NEM3 grew in $3 \%(\mathrm{w} / \mathrm{v}) \mathrm{NaCl}$ but not in $4 \%$.

Despite the phenotypic and ecological similarities, genomic heterogeneity exists within this group of isolates, such that its members are likely to represent more than one species. Certain characteristics (growth temperatures, differential ability to tolerate $\mathrm{NaCl}$ during growth, ability to utilize D-ribose and features of their fatty acid profiles) separate one group, NEM1 ${ }^{\mathrm{T}}$ and NEM1b, from NEM2 and NEM3, but there is little to separate the latter two isolates. Strain $\mathrm{NEM} 1 \mathrm{a}^{\mathrm{T}}$ grew in vivo (in infected insect hosts) with some, but not all Heterorhabditis spp. tested, while NEM2 and
NEM3 grew with a similar spectrum of Heterorhabditis spp., but different from that of NEM $1 \mathrm{a}^{\mathrm{T}}$ (M. R. Enright and C. T. Griffin, unpublished). Here, we propose isolates NEM1 ${ }^{\mathrm{T}}$ and NEM1b to represent a single species, Paenibacillus nematophilus sp. nov., with $\mathrm{NEM}^{\mathrm{T}}{ }^{\mathrm{T}}$ as the type strain. While NEM2 and NEM3 are phylogenetically very closely related to this proposed species, it is clear that they themselves are representative of at least one, but most likely two, novel species. To date, bacteria with these characteristics have been recovered only rarely fortuitously during the isolation of entomopathogenic nematodes from soil and the isolates studied here have been maintained in laboratory culture with nematodes for up to 10 years. Examination of further isolates from the wild (nematode-associated or otherwise) and of more phenotypic characters would be desirable so that the true extent of variation within these remaining potential species can be explored.

\section{Description of Paenibacillus nematophilus sp. nov.}

Paenibacillus nematophilus (ne.ma.to'phi.lus. N.L. n. nematoda nematode; Gr. adj. philos loving or having affinity for; N.L. adj. nematophilus nematode-loving).

Cells are rod-shaped, motile, 3.5-7·0 $\mu \mathrm{m}$ long and $0 \cdot 5-$ $1 \cdot 0 \mu \mathrm{m}$ wide. Cells stain Gram-negative (Gram-variable in older cultures). Oval-shaped endospores are produced in swollen, spindle-shaped sporangia and lie in a central/ paracentral position. Endospore is retained within the sporangium. Endospores measure on average $1.7 \times 1.2 \mu \mathrm{m}$, while sporangia are $6 \cdot 5-10 \cdot 6 \mu \mathrm{m}$ long. Relatively slowgrowing on nutrient agar, with colonies measuring 
$0 \cdot 5-4.0 \mathrm{~mm}$ in diameter. Colonies are thin, non-pigmented, regular, smooth and slightly umbonate with an undulate edge. Catalase-positive and oxidase-negative. Under anaerobic conditions, growth is weak and germination of endospores is poor compared with aerobic conditions. Grows in $2 \%$ but not $3 \%(\mathrm{w} / \mathrm{v}) \mathrm{NaCl}$. Grows optimally at $30^{\circ} \mathrm{C}$. Growth occurs at between 10 and $37^{\circ} \mathrm{C}$. No growth at 5 or $40^{\circ} \mathrm{C}$. Growth at $\mathrm{pH} 6-11$; no growth at $\mathrm{pH} 5 \cdot 6$. As determined with API $20 \mathrm{E}$ strips, $\beta$-galactosidase, arginine dihydrolase, lysine decarboxylase, ornithine decarboxylase, tryptophan deaminase and urease are not produced. Citrate is not utilized. Hydrogen sulfide, indole and $\mathrm{NO}_{2}$ are not produced. Gelatin is not hydrolysed. The Voges-Proskauer reaction is positive. Starch is hydrolysed. Casein and Tween 80 are not hydrolysed. Isolates are negative for egg yolk lecithinase activity. No colour change in litmus milk. In API $50 \mathrm{CHB}$ galleries, when API $\mathrm{CHB}$ suspension medium is used, aesculin is hydrolysed and acid but no gas is produced from D-glucose, methyl $\alpha$-D-glucoside, $N$-acetylglucosamine, amygdalin, arbutin, salicin, cellobiose, maltose, sucrose, trehalose, starch, glycogen and gentiobiose. Acid is produced at a slower rate from 5-keto-D-gluconate. Utilization of $\mathrm{D}$-mannose is variable (type strain is positive). Glycerol, ribose, erythritol, D-arabinose, L-arabinose, D-xylose, L-xylose, adonitol, methyl $\alpha$-D-xyloside, galactose, fructose, sorbose, rhamnose, dulcitol, inositol, mannitol, sorbitol, methyl $\alpha$-Dmannoside, lactose, melibiose, inulin, melezitose, raffinose, xylitol, D-turanose, D-lyxose, D-tagatose, D-fucose, L-fucose, D-arabitol, L-arabitol, gluconate and 2-ketogluconate can not be utilized as sole carbon sources. The major fatty acids are anteiso- $\mathrm{C}_{15}$ and $\mathrm{C}_{16: 0}$ and the $\mathrm{G}+\mathrm{C}$ content is approximately $44 \mathrm{~mol} \%$ as determined by HPLC. The type strain, strain $\mathrm{NEM}_{1} \mathrm{a}^{\mathrm{T}}\left(=\mathrm{DSM} 13559^{\mathrm{T}}=\mathrm{NCIMB} 13845^{\mathrm{T}}\right)$, and strain NEM1b were found associated with the entomopathogenic nematode $H$. megidis EU17 isolated from Estonia.

\section{Acknowledgements}

We are grateful to Dick Marti and Patricia Timper of USDA-ARS (Tifton, GA, USA), Seijo Elo (University of Helsinki) and Geoffrey McMullan (University of Ulster) for providing us with nematode/ bacterial isolates and information regarding them. We also thank Dieter Sturhan (Biologische Bundesanstalt für Land- und Forstwirtschaft, Münster) for the photograph.

\section{References}

Akhurst, R. J. (1982). Antibiotic activity of Xenorhabdus spp. bacteria symbiotically associated with insect pathogenic nematodes of the families Heterorhabditidae and Steinernematidae. J Gen Microbiol 128, 3061-3065.

Ash, C., Priest, F. G. \& Collins, M. D. (1993). Molecular identification of rRNA group 3 bacilli (Ash, Farrow, Wallbanks and Collins) using a PCR probe test. Proposal for the creation of a new genus Paenibacillus. Antonie van Leeuwenhoek 64, 253-260.

Cashion, P., Holder-Franklin, M. A., McCully, J. \& Franklin, M. (1977). A rapid method for the base ratio determination of bacterial DNA. Anal Biochem 81, 461-466.

Claus, D. \& Berkeley, R. C. W. (1986). Genus Bacillus Cohn 1872, $174^{\mathrm{AL}}$. In Bergey's Manual of Systematic Bacteriology, vol. 2, pp. 1105-1139. Edited by P. H. A. Sneath, N. S. Mair, M. E. Sharpe \& J. G. Holt. Baltimore: Williams \& Wilkins.

De Ley, J., Cattoir, H. \& Reynaerts, A. (1970). The quantitative measurement of DNA hybridization from renaturation rates. Eur J Biochem 12, 133-142.

Elo, S., Suominen, I., Kämpfer, P., Juhanoja, J., Salkinoja-Salonen, M. \& Haahtela, K. (2001). Paenibacillus borealis sp. nov., a nitrogenfixing species isolated from spruce forest humus in Finland. Int J Syst Evol Microbiol 51, 535-545.

Enright, M. R., Finnegan, M. M., McInerney, J. O., O'Laighleis, M. \& Griffin, C. T. (2001). Specific adherence of sporangia of a Paenibacillus sp. bacterium to Heterorhabditis spp. nematodes. Hitching a ride to lunch? In Developments in Entomopathogenic Nematode/Bacteria Research, pp. 301-306. Edited by C. T. Griffin, A. M. Burnell, M. J. Downes \& R. Mulder. Brussels: European Commission.

Escara, J. F. \& Hutton, J. R. (1980). Thermal stability and renaturation of DNA in dimethyl sulfoxide solutions: acceleration of the renaturation rate. Biopolymers 19, 1315-1327.

Felsenstein, J. (1988). Phylogenies from molecular sequences: inference and reliability. Аnnu Rev Genet 22, 521-565.

Forst, S. \& Nealson, K. (1996). Molecular biology of the symbioticpathogenic bacteria Xenorhabdus spp. and Photorhabdus spp. Microbiol Rev 60, 21-43.

Forst, S., Dowds, B., Boemare, N. \& Stackebrandt, E. (1997). Xenorhabdus and Photorhabdus spp.: bugs that kill bugs. Annu Rev Microbiol 51, 47-72.

Galtier, N., Gouy, M. \& Gautier, C. (1996). SEAVIEW and PHYLO_WIN: two graphic tools for sequence alignment and molecular phylogeny. Comput Appl Biosci 12, 543-548.

Gordon, R. E., Haynes, W. C. \& Pang, C. H. (1973). The Genus Bacillus. Agriculture Handbook no. 427. Washington, DC: United States Department of Agriculture.

Griffin, C. T., Dix, I., Joyce, S. A., Burnell, A. M. \& Downes, M. J. (1999). Isolation and characterisation of Heterorhabditis spp. (Nematoda: Heterorhabditidae) from Hungary, Estonia and Denmark. Nematology 1, 321-332.

Heyndrickx, M., Vandemeulebroecke, K., Hoste, B., Janssen, P., Kersters, K., De Vos, P., Logan, N. A., Ali, N. \& Berkeley, R. C. W. (1996a). Reclassification of Paenibacillus (formerly Bacillus) pulvifaciens (Nakamura 1984) Ash et al. 1994, a later subjective synonym of Paenibacillus (formerly Bacillus) larvae (White 1906) Ash et al. 1994, as a subspecies of $P$. larvae, with emended descriptions of $P$. larvae as $P$. larvae subsp. larvae and P. larvae subsp. pulvifaciens. Int J Syst Bacteriol 46, 270-279.

Heyndrickx, M., Vandemeulebroecke, K., Scheldeman, P., Kersters, K., De Vos, P., Logan, N. A., Aziz, A. M., Ali, N. \& Berkeley, R. C. W. (1996b). A polyphasic reassessment of the genus Paenibacillus, reclassification of Bacillus lautus (Nakamura 1984) as Paenibacillus lautus comb. nov. and of Bacillus peoriae (Montefusco et al. 1993) as Paenibacillus peoriae comb. nov., and emended descriptions of $P$. lautus and of P. peoriae. Int J Syst Bacteriol 46, 988-1003.

Huß, V. A. R., Festl, H. \& Schleifer, K. H. (1983). Studies on the spectrometric determination of DNA hybridization from renaturation rates. Syst Appl Microbiol 4, 184-192.

Jahnke, K.-D. (1992). Basic computer program for evaluation of spectroscopic DNA renaturation data from GILFORD System 2600 spectrometer on a PC/XT/AT type personal computer. J Microbiol Methods 15, 61-73.

Krieg, A. (1981). The genus Bacillus: insect pathogens. In The Prokaryotes, pp. 1743-1755. Edited by M. P. Starr, H. Stolp, H. G. Trüper, A. Balows \& H. G. Schlegel. Berlin, Heidelberg \& New York: Springer. 
Logan, N. A. \& Berkeley, R. C. W. (1984). Identification of Bacillus strains using the API system. J Gen Microbiol 130, 1871-1882.

Marti, O. G., Jr \& Timper, P. (1999). Phoretic relationship between a Bacillus sp. and the entomopathogenic nematode, Heterohabditis sp. J Nematol 31, 553.

Meehan, C., Bjourson, A. J. \& McMullan, G. (2001). Paenibacillus azoreducens sp. nov., a synthetic azo dye decolorizing bacterium from industrial wastewater. Int J Syst Evol Microbiol 51, 1681-1685.

Mesbah, M., Premachandran, U. \& Whitman, W. B. (1989). Precise measurement of the $\mathrm{G}+\mathrm{C}$ content of deoxyribonucleic acid by high-performance liquid chromatography. Int J Syst Bacteriol 39, 159-167.

Nakamura, L. K. (1996). Paenibacillus apiarius sp. nov. Int J Syst Bacteriol 46, 688-693.

Parry, J. M., Turnbull, P. C. B. \& Gibson, J. R. (1983). Methods and characterisation tests. In A Colour Atlas of Bacillus Species, pp. 14-51. London: Wolfe Medical.

Pettersson, B., Rippere, K. E., Yousten, A. A. \& Priest, F. G. (1999). Transfer of Bacillus lentimorbus and Bacillus popilliae to the genus Paenibacillus with emended descriptions of Paenibacillus lentimorbus comb. nov. and Paenibacillus popilliae comb. nov. Int J Syst Bacteriol 49, 531-540.

Poinar, G. O., Jr (1990). Biology and taxonomy of Steinernematidae and Heterorhabditidae. In Entomopathogenic Nematodes in Biological Control, pp. 23-62. Edited by R. Gaugler \& H. K. Kaya. Boston: CRC Press.

Shida, O., Takagi, H., Kadowaki, K., Nakamura, L. K. \& Komagata, K. (1997a). Transfer of Bacillus alginolyticus, Bacillus chondroitinus,
Bacillus curdlanolyticus, Bacillus glucanolyticus, Bacillus kobensis, and Bacillus thiaminolyticus to the genus Paenibacillus and emended description of the genus Paenibacillus. Int J Syst Bacteriol 47, 289-298.

Shida, O., Takagi, H., Kadowaki, K., Nakamura, L. K. \& Komagata, K. (1997b). Emended description of Paenibacillus amylolyticus and description of Paenibacillus illinoisensis sp. nov. and Paenibacillus chibensis sp. nov. Int J Syst Bacteriol 47, 299-306.

Smibert, R. M. \& Krieg, N. R. (1994). Phenotypic characterization. In Methods for General and Molecular Bacteriology, pp. 607-654. Edited by P. Gerhardt, R. G. E. Murray, W. A. Wood \& N. R. Krieg. Washington, DC: American Society for Microbiology.

Stackebrandt, E. \& Goebel, B. M. (1994). Taxonomic note: a place for DNA-DNA reassociation and 16S rRNA sequence analysis in the present species definition in bacteriology. Int J Syst Bacteriol 44, 846-849.

Strimmer, K. \& von Haeseler, A. (1996). Quartet puzzling: a quartet maximum-likelihood method for reconstructing tree topologies. Mol Biol Evol 13, 964-969.

Tamaoka, J. \& Komagata K (1984). Determination of DNA base composition by reversed-phase high-performance liquid chromatography. FEMS Microbiol Lett 25, 125-128.

Thompson, J. D., Gibson, T. J., Plewniak, F., Jeanmougin, F. \& Higgins, D. G. (1997). The CLUSTAL_X windows interface: flexible strategies for multiple sequence alignment aided by quality analysis tools. Nucleic Acids Res 25, 4876-4882.

Wayne, L. G., Brenner, D. J., Colwell, R. R. \& 9 other authors (1987). Report of the ad hoc committee on reconciliation of approaches to bacterial systematics. Int J Syst Bacteriol 37, 463-464. 